\title{
ISLAMIC SHARIA AND NON-MUSLIM CITIZENS IN KANUNNAME DURING SULTAN ABDUL HAMID II OF THE OTTOMAN EMPIRE
}

\author{
MEIRISON ALIZAR*1, QASIM MUHAMMADI ${ }^{2}$ \\ ${ }^{1}$ Universitas Islam Negeri Imam Bonjol Padang \\ ${ }^{2}$ International Cultural Center of Rahmatun lil Alamin, Iran
}

\section{Abstract}

The tolerant spirit of Islam has inspired Ottoman rulers to adopt policies relating to non-Muslim citizens. The leadership crisis in the Ottoman Empire and the Western interests through capitulation have changed the judicial system in the empire, including the system for the non-Muslims that allows them to conduct their judiciary and provide absolute freedom of religious matters. Tanzimāt, which is expected to bring improvements to the legislation system in Ottoman Empire, has marginalized Islamic law which is only enforced in ahwāl al-shakhșiyyah. Sultan Abdul Hamid II tried to maintain Islamic law by codifying Western European style. Some legal codifications contain qawaid fiqhiyyah (principles of Islamic law) which are sourced from the books of the Hanafi School of jurisprudence, and some others adopt Western laws by taking a few opinions of Islamic jurisprudence. This study analyzed various literatures related to policies towards non-Muslim citizens in the Ottoman era. The study uses descriptive and qualitative methods with a content analysis approach. Broadly speaking, this study found that the Ottoman Empire had given proper treatment to non-Muslim citizens. The non-Muslim citizens get various facilities from the State, including the establishment of special institutions that handle their affairs, although at the same time they

\footnotetext{
* Corresponding author: Jl. Prof. Mahmud Yunus Lubuk Lintah, Padang, Sumatra Barat, Indonesia. E-mail: meirison@uinib.ac.id.
} 
have been used by Western countries to support their interests in Ottoman Empire.

Ruh Islam yang toleran telah mengilhami para penguasa Turki Usmani dalam mengambil kebijakan berkaitan dengan warga negara non-Muslim. Krisis kepemimpinan di Turki Usmani dan kepentingan Barat melalui Kapitulasi telah merubah sistem peradilan di Turki Usmani, termasuk sistem peradilan berkaitan dengan non-Muslim yang memungkinkan mereka menyelenggarakan peradilan sendiri dan memberikan kebebasan mutlak tentang urusan agama. Tanzimat, yang diharapkan dapat mendatangkan perbaikan terhadap sistem legislasi di Turki Usmani, telah memarjinalkan bukum Islam yang hanya diberlakukan dalam masalah ahwāl as-syakhsiyyah. Sultan Abdul Hamid II mencoba mempertahankan hukum Islam dengan melakukan kodifikasi bergaya Eropa Barat. Beberapa kodifikasi hukum berisi qawāid fiqh yang bersumber dari kitab-kitab fikih mazhab hanafi, dan beberapa kodifikasi lainnya mengadopsi hukum-hukum Barat dengan mengambil sedikit pendapat-pendapat fikih Islam. Studi ini menganalisis berbagai literatur terkait kebijakan berkaitan dengan warga non-Muslim di masa Turki Usmani. Kajian ini menggunakan metode deskriptif dan kualitatif dengan pendekatan analisis konten. Secara garis besar, kajian ini menemukan babwa Turki Usmani telah memberikan perlakukan yang baik terhadap warga non-muslim. Mereka mendapatkan berbagai fasilitas dan kemudahan dari Negara, termasuk pendirian lembaga khusus yang menangani urusan mereka, meskipun di saat yang sama mereka telah dimanfaatkan oleh negara-negara Barat untuk mendukung kepentingan mereka di Turki Usmani.

Keywords: Islamic Sharia; Kanunname; Non-Muslims; Ottoman Empire; Sultan Abdul Hamid II.

\section{Introduction}

In the early days of Islam, it was quite clear that justice and judiciary could be realized without sacrificing anything in Islamic sharia or law. Islamic sharia can be fully enforced without in- 
tervention and excessive tolerance towards non-Muslims, whose rights have been guaranteed by Rasulullah PBUH. However, cultural friction with other people over a long period of time has changed many Muslim traditions. In this case, Muslims no longer fully adhere to Islamic law and 'ilm (knowledge), which must be sought for every male and female Muslims. The door to ijtihad seems locked, while the interpretation of the Qur'an and the Hadith, as well as ijma (ulema consensus) is difficult, especially when dealing with actual problems.

After the Hanafi School has been made as a compulsory curriculum, interpretation is no longer sourced directly from the Qur'an and Hadith through qiyās, but fiqh books from the Hanafi School. Because of this interpretation problem, the authorities then issued their own rules, known as Kanunname, insofar as they did not conflict with the Islamic law. Gradually, this phenomenon led to the birth of dualism in the legal and judicial system. In a later development, the points in the Kanunname made by considering the existence of this minority group are viewed far from the spirit of Islamic law. The dualism between Islamic sharia and Kanunname has facilitated the process of legal capitulation and foreign intervention on Ottoman Turkish policies during the crisis (Quataert 2005, 167).

At the beginning of the $14^{\text {th }}$ century $\mathrm{AD}$, a small kingdom on the border of the Seljuk and Byzantine territories was born (Finkel 2007, 21). In a short time, this kingdom was transformed into an empire whose territory was spread over three continents covering a variety of different ethnicities, religions, languages, and cultures. Discussion in this study was carried out inductively, and it included the relationship between the Ottoman Empire and the non-Muslim minority groups under its aegis. This study does not intend to describe the historical records in detail, but it rather focuses on the manifestations of tolerance of Islamic 
teachings carried out by the Ottoman rulers, especially towards the non-Muslim minority groups. During the Ottoman era, positive laws called Kanunname that were applied according to Islamic law had been widely issued. The issuance of Kanunname has led to the legal and judicial dualism between the Ottoman Turkish law and Islamic law. At that time, there were Islamic courts and district (regular) courts. The term al-Kanun itself had existed in the 11th century $\mathrm{AD}$, but it began to be used popularly in the Ottoman era. The term is often associated with $\mathrm{Ka}$ nunname which consists of a collection of rules and regulations that are compiled and codified in a concise form. The rules were made based on the Shaykhul Islam fatwa at the request of the government and the firmans. ${ }^{2}$

Kanunname contains matters relating to administration, punishment, and others. It is made to maintain public and private benefits, as long as it does not contradict the Islamic sharia; it is based on the siyasa shari'iyyah and maqāșid al-sharia. The Ottoman Empire had a vast territory consisting of various ethnic groups, sects, and religions. They are connected in a legal and political system that is dynamic, as it accommodates social changes. These social changes generally require the separation of law, i.e. between the sharia law and the positive law (Kanunname) or between the Islamic and the regular courts. This separation refers to the mandate of reform or tanzimat (Belge 1985) which began in $1839 \mathrm{AD}$ and the era of Khath Hamayun as-Syarif $1856 \mathrm{AD}$ as a form of legal protection for non-Muslim communities in the $19^{\text {th }}$ century AD in the Ottoman Empire and the Europe.

During Sultan Abdul Hamid II, the Ottoman Empire came under pressure from Western Europe in the form of restrictions on power through a constitutional declaration. At that time, the

\footnotetext{
${ }^{2}$ Firman is a Turkish term meaning the words of the sultan or king.
} 
constitution was implemented artificially; the parliament never holds a meeting while its members continue to receive salaries for life. The sultan acted as the sole ruler of the Ottoman Empire because he had lost trust in the parliament which urged the sultan to fight with Russia in 1877, known as the War of 93.

Medhat Pasha agitated religious students and the community so that the Ottoman Empire would fight against Russia. This agitation was successful, and Turkey finally lost. According to the constitution, the Sultan must not interfere in government affairs. Therefore, Sultan Abdul Hamid II is considered a dictator. However, the German politician named Bismark justified the sultan's actions by saying: "If the power of the State does not come from one person, the harm done by his council will be greater than the benefits" (Ihsan Oglu, Akmaluddin dan Sa'dawi, Salih 2011, 166). The defeat of the war experienced by the Ottoman Empire was due to the influence of Western European intimidation against the majority of council members. This condition is very detrimental to the Ottoman Empire, where all state institutions and policies are directly connected to Sultan Abdul Hamid II.

During the time of Sultan Abdul Hamid II, the military did not interfere in domestic affairs even though it was still involved in security matters. The military did not use force in carrying out governmental duties, except for a small amount. Sultan Abdul Hamid II's reign was far from bloodshed, murder, or the removal of political opponents. He rarely sentenced them to prison, except for sending into exile. During his reign of more than 30 years, he only sentenced them to death five times. This number was the least in Ottoman Turkish history. The question is: what caused changes in the legal structure and governance of Sultan Abdul Hamid II? Is it because non-Muslims don't get justice from the Ottoman Empire that they need to be under the pro- 
tection of Western Europe and Russia? How is the policy implementation of Kanunname towards the non-Muslims?

Changes in the legal structure and governance of the Ottoman Empire are inevitable. Turkey has adopted the law of nationalism, which officially crystallized on January 19, 1869 AD. In accordance with this law, all people who live in the Ottoman territory are citizens of the Ottoman Empire, regardless of their religions. Ottoman citizenship can be obtained because of heredity, nationality, or marriage. Since then, national ties have replaced religious ties. There is no distinction between Muslims, dhimi or musta'min (the non-Muslim parties protected by law). All legal status based on religion has been abolished (Abdullah 1973, 44). Relations between citizens have been replaced by nationalism values. This fact encourages ahlu-dhimah (non-Muslim citizens) to ask for protection from foreign countries that have the right of capitulation, or legal privileges in the form of tax breaks and immunity to local laws. The relationship between the state and individuals, which is no longer based on religion, requires that everyone has proof of citizenship. Without this proof, one is seen as a foreigner who is not entitled to get services or assistance, even though she or he is a Muslim. At this point, European law began to flood Ottoman Empire, while Islamic law seemed to be marginalized within the scope of a bwāl

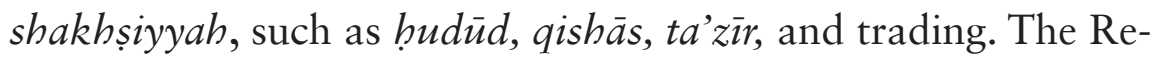
form or Tanzimat has diminished the power of the sharia court. The 'closed' door of ijtihad is also one of the factors triggering the dualism of the legal and judicial system in the Ottoman Empire. As known, the Ottoman Empire has only held to the Hanafi School of thought since the time of Sultan Salim I (1512-1520 $\mathrm{AD})$.

Laws other than Islamic law are often enforced and sometimes conflict with Islamic law itself, although they were origi- 
nally issued to fill the legal vacuum for the sake of goodness. The codification of the Hanafi School of fiqh in the Ottoman Empire which was carried out in 1876 to facilitate the application of Islamic law in the sharia courts contained matters of worship and $m u^{\prime}$ 'amalāt in the narrow sense, not jinayāt. Trade laws issued in 1850, as well as criminal and land law in 1858, all refer to Western laws, especially France and Switzerland, which are sometimes no longer used in their home countries (Ebru Aykut 2017,21). The enactment of these laws was carried out at the urging of the Western World as a donor country for the debts of the Ottoman Empire. Meanwhile, Kanunname is part of the siyasa shari'iyyah which is intended to complete ijtihad to bring about benefit and justice. Therefore, every law that is issued should be adjusted to Islamic law through the fatwa of Shaykh al-Islam (Inalcik 2013, 121).

Halil Inalcik, professor of Ottoman Turkish history from Cambridge University who wrote a book titled Ottoman Turks min Nusyü' Ilā Inhidār, explained the conflicting Kanunname and Islamic Sharia and considered the process of issuing rules in the Kanunname as secular law. In line with Halil, Donald Quataert, history professor from Binghamton University in his book The Ottoman Empire 1700-1922 (New Approaches to European History), explained that the decline of the Ottoman Empire was a result of capitulation of law and the internal and external pressures without in-depth discussion of legal aspects and their source (Quataert 2005). Şevket Pamuk, in his book entitled A Monetary History of the Ottoman Empire helped explain the background of the capitulation agreement from the monetary and economic aspects which then affected the entire economy of the Ottoman Empire. According to him, what must be addressed in the Ottoman Empire at that time were economic problems and their support, such as technology, not the legal and judicial system. 
The novelty of this study can be seen from the focus of its discussion on the state institutions that specifically deal with minority issues during Sultan Abdul Hamid II. These institutions often favour minority groups than the Muslim community. The results of the ijthād of fiqh (Islamic law) about minority groups in the Ottoman Turks consisting of patriarchs have been recognized by the Orthodox Church Qanun as a sign of Islamic tolerance in the Ottoman Empire (Syahatah 2016, 22). In this study, the writer also discusses absolute freedom of religion and justice to non-Muslim groups during the time of Sultan Abdul Hamid II even though he was described as a dictator. The writer also tries to explain the impact of the dualism of the judicial system and capitulation in the Ottoman Empire, which contributed to the collapse of a 600-year-old empire that once dominated world politics. In addition, the role of minorities in foreign capitulation agreements which have become the entry point for foreign intervention in the field of law against non-Muslims is also discussed here. Foreign capitulation has been exploited by minority groups in various fields, be it in the fields of law, economics, and politics, so that Islamic law is marginalized as it applies only in the case of abwāl al-shakhșiyyah.

This study uses a qualitative method with literature study. Here, the writer concludes deductively through literature review about the relationship between Islamic law and the Kanunname, and the role of the Kanunname in creating harmony in the religious community during the Ottoman Empire. Problem-solving procedures are carried out through sources (books) that can describe the state of the subject or object of research on the application of sharia, the judicial system, and the conditions of minority groups during the Ottoman Empire. The writer will describe the facts about the problem being investigated as they are, followed by rational and balanced interpretations. As 
a benchmark and basis for analysis, he uses the main points of the siyasa shar'iyyah of the caliphs, a period after the Prophet Muhammad, as follows:

\section{Protection of Non-Muslims in the Early Period of Islam}

\section{Protection of Property}

Abu Yusuf narrated some of the contents of the Prophet Muhammad's agreement with the Najran Christians, “... for the people of Najran and their followers were given the guarantee of Allah and the dhimmah of Muhammad, His prophet and messenger, for their possessions, places of worship, and whatever under their control, both the few and the many ...” (Abu Yusuf Al-Kharāj, 15-16). The details of the agreement are whoever steals the property of a dhimmi will have his hand chopped off; he who seizes will be punished, and the property will be returned to its owner; he who owes to ablu dhimmi must pay; and whoever deliberately stalled his payment while he is able, the judge will imprison him until he is willing to pay the debt.

\section{Protection of Honor}

The Book of Al-Durrul Mukhtār states that, "(Muslims) are obliged to prevent interference with a dhimmi, and they are also prohibited (haram) to gossiping about him, as about a Muslim". Ibn Abidin explained, "With the dhimmah agreement, a non-Muslim has the same rights as the Muslims." Therefore, as a prohibition against gossiping Muslims, it is also forbidden to gossip about a dhimmi. Some scholars believe that committing tyranny $(z \bar{a} l i m)$ against a dhimmi is greater in sin (than against fellow Muslims)".

Religious Freedom

Islam does not force other people to convert to Islam. Allah has said, "There is no compulsion to convert to Islam; it is clear the right way and the wrong way" (al-Quran, al-Baqarah: 
256). Despite providing several restrictions, Umar bin Khațtab is known as a religious tolerance figure in the land of Palestine. When conquering Jerusalem in $636 \mathrm{AD}$, he signed the Aelia Agreement with the losing party, as follows:

"Bismillāh al-Rahmān al-Rahìm. This is the guarantee given by the servant of Allah named Umar Amìrulmukminin to the People of Aelia, namely the guarantee of salvation for souls and possessions, for the churches and crosses, for the sick and the healthy, and other religious groups. Their churches must not be occupied, torn down, reduced from within or within their environment, either their crosses or their property. Neither of them should be disturbed"(At-Tabari 2016, 609).

\section{Justice towards Non-Muslims}

One time Ali bin Abi Talib R.A lost his armour. One day he found the armour on a Christian. Then, both of them filed the case before Judge Shuraih. During the trial, Ali was unable to present a witness that the armour was his. Therefore, the judge ruled that the armour belonged to the Christian. Khalifah Ali accepted the decision sincerely. Seeing the justice of the judge and Caliph Ali, the Christian also admitted that the armour belonged to Ali who had fallen in a battle and he took it. He claimed to embrace Islam. But, the Caliph replied, "Now, because you converted to Islam, I have given that armour to you" (Ibn Kathir, 1988, 4-5).

\section{Social Justice towards Non-Muslims}

One day Amir al-Mu'minin Umar ibn Khatab passed by a door of someone's house. Near Umar was a beggar, and the beggar raised his hand at Umar. That person is old and blind. He said, "I ask for jizyah, needs, and age", so Umar took his hand, went to his house, and gave what he asked for. After that, Umar went to Baitul Mal and said to his treasurer, "Pay attention to people like this and such. We are not fair to him; we have eaten 
his youth, then we humiliate him when he is old. We cancel $j i$ zyah to people who are the same fate as him" (Nurul Huda dan Muti 2002, 29).

\section{Kanunname and Legislation Problems}

Muslim fuqaha argue that the Kanunname does not need to exist, as is the opinion of Muslim sociologist and economist named Ibn Khaldun. The legal instruments in Islamic law are complete and can answer every legal problem, both in the present and in the future. However, some scholars believe that as long as the Kanunname does not contradict the Islamic sharia, is according to customs, and can be used as a rule in the qiy $\bar{a} s$ for the benefit of the Muslims, this Qanun is permissible (Inalcik 2013, 161). Kanunname was attributed to Sultan Sulaiman I (1495-1566 AD) at the end of the 15th century, even though it had begun since the conquest of Constantinople (1453 AD) by Sultan Muhammad al-Fatih. However, in reality, clashes often occur between Kanunname and Islamic law, such as compensation for theft, adultery, and various types of violations with money. In addition, foreign capitulation has also hindered the application of Islamic law and the Kanunname in civil and criminal law because non-Muslims can have legal immunity by purchasing capitulation certificates or by having multiple nationalities even though they have never visited a European country (Ahmad 2000, 111).

\section{Legislation Process}

The Turkish rulers do not want their political space limited. In Turkey, laws and regulations existed long before the Ottoman Empire existed. Rules and laws are issued in the form of firmans or words (king's or sultan's decree). Each newly appointed sultan will stipulate existing laws and regulations. Meanwhile, sharia is a permanent constitution. Therefore, every firman that 
is issued must be in line with Islamic law and the beforehand-existing Kanunname.

The Ottoman Qanun is divided into three forms: (1) rules which have legal consequences issued by the sultans under certain conditions. These thousands of regulations are recorded in the form of documents which become general laws in the Ottoman Empire; (2) rules related to specific fields or for certain strata of society; and (3) Kanunname that applies throughout the Ottoman territory.

Most laws and regulations originate from the central government in Istanbul for specific purposes or the resolution of administrative problems. The minutes compile them in the form of firmans. After being reviewed and seen perfect, the prime minister and the supreme judge appear before the sultan to seek verbal or written approval. Sometimes, the sultan issues orders or firmans without any prior process. The compilation of Kanunname is the task of the Nisanji (the supreme judge).

\section{The Ottoman Law and Sharia Distinction}

The sultans, by referring to the siyasa shar'iyyah rules, issued laws and general regulations related to administrative, economic, social, legislative, and financial matters to be applied in each region. Their policies are named Kanunname and are a collection of rules issued to regulate state affairs within the scope of sharia. Therefore, Kanunname is a collection of laws derived from Islamic Sharia (Shadiq Janbulat 2012, 309).

These rules-making authorities (tashri ${ }^{6}$ ) are gradually centralized to the Ottoman Turkish sultans, especially since the door to ijtihad is seen to be closed. Nevertheless, the authorities are still bound by the texts and the basics of sharia. This legislation matter is complementary, that is when legal status is not found in the sharia. After the khiläfah system was transferred to the Turkish hands, the meaning and position of the khiläfah be- 
gan to fade. Many rulers are incompetent in carrying out siyāsah shar'iyyah. The legislation process only deals with general cases and not cases that must be referred to Islamic law, especially during the tanzimat and after that which have undergone social and economic changes, as well as thoughts (Mughal dan Sadiki 2017, 221).

The legislation was issued in the form of the firmans of the sultan or whoever given a mandate for it. Before issuing the firman, the sultan usually discussed it with the Shaykh al-Islam. Some laws are general and apply to the whole region, and others are specific and apply to certain regions only. Some laws are detailed and relate to individual and public ownership, and some are private such as the appointment and resignation of a person from office. In general, the enactment of legislation during the Ottoman Empire rested on siyasāh syar'iyyah until the beginning of the $19^{\text {th }}$ century. After that, this Empire began to turn away from the siyasa shari'iyyah and adopt laws that were in conflict with Islamic law. The Empire was considered excessive in applying the laws adopted from the West. The Ottoman Empire also applied laws that contradicted the Islamic sharia in the Islamic regions under its control (Inalcik 2013, 112).

\section{The Issuance of Majalla Ahkām al-'Adliyah}

Majalla abkām al-'adliyah is an innovation in the codification of Islamic jurisprudence in the Ottoman Empire. Previously, the codification was only limited to a particular material and was spread sporadically in the capital city or major cities (trading centres). Scientific factors motivate the preparation of majalla abkām al-'adliyah. It is very much needed because the teachings of Islam have various schools of thought and ijtihad. Even differences of opinion also occur in the same school. Majalla abkām al-'adliyah serves to sort out and differentiate weak and strong views along with the postulates used. 
Majalla abkām al-'adliyah is an improvisation of the wave of renewal coming from Western Europe in the field of codification of modern law. It makes an easy way for judges, who are not yet experienced with fiqh opinions and fiqh rules, to find legal references when deciding a case. As known, at that time, the judges and judicial officers suffered a setback in the understanding and application of Islamic law in connection with new situations. The fuqaha in the Ottoman Empire were not the mujtahid mustaqil (independent mujtahid) who could express their own opinions, but those who only held the view of the Imam of the School (the Hanafi School). In this case, majalla abkām al-'adliyah only presents strong opinions without describing differences of opinion in fiqh, so that legal decisions can be reached more easily (Aviv 2016).

Majalla abkām al-'adliyah is a form of the struggle of Sultan Abdul Hamid II, scholars and society at that time so that Islamic law can still survive in the midst of a wave of secularism in all fields. Thus, Islamic law can continue to be applied, namely by updating the drafting and systematics of the law while the material remains in reference to Islamic jurisprudence, especially the Hanafi school of law (Kazıcı 2009, 78).

The Form of Majalla Abkām Al-'Adliyah

Majalla abkām al-'adliyah was composed in 1851 AD, consisting of preamble and 16 chapters. It is a kind of paper adapted from the text of the Hanafi School of jurisprudence. This sort of magazine is a codification of Hanafi fiqh adjusted to the problem at that time. It contains theories of aqad (contracts) in general and their consequences. The author does not intend to adapt the content to the principles of fiqh in general. The material is discussed without including any background according to general rules (Braude and Lewis 1982). 
Majalla abkām al-'adliyah is the product of tanzimat in the field of codification of law that has been adapted to Western law in form and method. However, the material still refers to the Islamic sharia of the Hanafi School. It also explained the principles of fiqh totalling 99 principles. Thus, attention to the rules of fiqh becomes more focused. In addition, there were also comments from ulema who helped enrich and perfect the contents of the magazine. The issuance of majalla abkām al-'adliyah had quite extensive influence, as can be seen in trade laws in the United Arab Emirates, Jordan and Yemen. It has provided innovations in the fiqh method and, accordingly, distinguished scientific jurisprudence, educational regulations, and judicial laws. Numbering is made in the order of the problem. Opinions used in the majalla are only those which are considered strong by the author without including differences in fiqh opinions from the ulema.

Majalla abkām al-'adliyah must be referred to courts because the magazine is published by official order of the sultan. The Majalla was applied in Turkey (Anatolia), Syria, Palestine, Lebanon, Iraq, but it was not implemented in Egypt because it had gained special autonomy in the field of law and governance since 1873 AD. Since, during the Khedive Ismail era, Egypt had adopted laws and regulation from France, then civil law was issued in 1873 and mixed law in 1875. Islamic sharia in Egypt is only limited to al-shakhșiyyah, while others apply the Napoleonic law (Mahmashani 1980, 90-100).

Kanunname as an Authoritative Act

After the door to ijtihad was closed, there was a gap between the Islamic sharia and the qanun (laws). Qanun is all orders originating from the sultan as the implication of government authority in Islamic law. Meanwhile, the term shara' is identical to the rules and laws contained in the book of fiqh that adheres 
to the Qur'an, Sunna, ijma', qiyās, istiḥsān, and so on. All laws that will be issued are shown to the Shaikh al-Islam, so that they are in line and not in conflict with the sharia.

The closed-door of ijtihad caused the legislative authority to move from the mujtahidin to the rulers, sultans, or caliphs. Sharia law is anything that has been mentioned in fiqh books. Many problems are not found in the fiqh books, especially in the Hanafi School. Under these conditions, the sultan issued a decree, whether or not they came from his understanding of the sharia, as long as they were in line with the spirit of the Islamic sharia. In Turkish, these decrees are called Kanunname (Ágoston dan Masters 2009, 22). The Kanunname has four periods. The first is from the establishment of the Ottoman Empire to the time of Sultan Muhammad al-Fātih. The second is from the time of Sultan Muhammad al-Fātih to the time of Sultan Salim I. The third is from the time of Sultan Salim I to the tanzimat. The fourth is from the tanzimat until the collapse of the Ottoman Empire (Shadiq Janbulat 2012, 20). Kanunname is part of the siyasa syar'iyyah which is made to perfect the building of Islamic fiqh legislation. Islamic fiqh itself recognizes the role of government as a decision-maker in the broadest sense for the benefit of the people. The basis for the making of Kanunname is to realize justice and goodness (Mantran 2003, 223).

The idea of qanun or the law did not come alone, but rather a legacy from previous countries, such as the laws applied by Gengis Khān. The law was then rearranged by the Ottoman Empire to conform to Islamic teachings (Sadiq Janbulat 2012, 21). The tarjī initiated by the Hanafi scholars has made Ottoman sultans more free in issuing laws based on the opinions of the jurists at that time, whether Hanafi-based or not. However, the Ottoman Empire seems to have exceeded the limits of the siyasa syar'iyyah by adopting foreign (Western) laws to be applied in 
their country. The Ottoman Empire issued legal products in the name of the firmans, khat al-sharif, or irädah sinniyyah which led to the Kanunname. In further developments, the drafting of the laws leads to civil law. Then, majalla abkām al-'adliyah was composed in 1869-1876 AD by following the Hanafi School. The stagnation in ijtihad has created the creation of new laws because of social changes. The rulers in the Ottoman Empire took practical steps in regulating administration, judicial system, and mu'āmalat by adopting Western laws (Zarqa 2001, 166). The Ottoman government adhered to Islamic sharia in drafting the laws until the mid-19th century AD (Mughal dan Sadiki 2017, 154).

\section{Non-Muslim Minority in Kanunname}

The Ottoman Empire is vast and inhabited by various ethnic groups from three continents. They have different religion and belief backgrounds. The religions recognized by the Ottoman Empire were only three: Islam, Christianity, and Judaism, although there were many other beliefs held by more than 60 ethnic groups.

\section{Regional Islamic Sharia as the Basis for Religious Tolerance}

Islamic sharia is a law that must be applied in Islamic territory (Dar al-Islam). A Muslim qadi must apply Islamic law in resolving cases, be it matters involving Muslims or non-Muslims, as was done during the time of Khulafa ar-Rashidin (Qaradawi 1992, 27). As a manifestation of Islamic tolerance, the State allows non-Muslims to consume liquor, eat pork, get married, and do talāq according to their tradition. They are not burdened with carrying out Islamic law, as explained in the Qur'an. However, they are allowed to choose between settling matters with Islamic law or non-Islamic law. The Qur'an explains:

And let the People of the Gospel judge by what Allah has revealed therein. And whoever does not judge by what Allah has 
revealed - then it is those who are the defiantly disobedient (al-Māidah: 47).

[They are] avid listeners to falsehood, devourers of [what is] unlawful. So if they come to you, [O Muhammad], judge between them or turn away from them. And if you turn away from them - never will they harm you at all. And if you judge, judge between them with justice. Indeed, Allah loves those who act justly (al-Māidah: 42).

The State also prepares non-Muslim judges, such as for Coptic community in Egypt in the Millet court during Ottoman Empire to handle non-Muslim cases. They applied their respective sharia, especially regarding the matter of abwāl shakhșiyyah (Ebru Aykut 2017, 166). Religious ties were the basis for establishing law in the territory of the Ottoman Empire, before the nationalism ties were applied at the end of the $19^{\text {th }}$ century $\mathrm{AD}$. After the Ottoman turned to secular law, there were no more differences in law (Haqi 1988, 356). The applied law is the law adopted from the West, both in civil and criminal matters, except in connection with the abwāl shakhșiyyah (Farid Bek Al-Muhami 2009, 256). Aḅwāl shakhșiyyah is handled by the religious court, while those related to the property are processed by positive laws. The civil court was declared in 1875 and renewed in $1948 \mathrm{AD}$ without the slightest involvement of Islamic law, including matters of marriage and divorce, or the non-Muslim law (Zuhaili 1992, 316).

\section{Islamic Sharia and Non-Muslim Minority Issues}

Non-Muslim sharia is often debated and misunderstood. What is meant by the non-Muslim sharia is the interpretation of Islamic religious leaders derived from the samawiah books and the traditions of religions. The sources of the Jewish and Christian sharia are the Torah and the Gospel, a collection of apostolic letters, readings of public and special assemblies, laws 
originating from bishops, opinions of Ablul Kitab published by previous popes, and other similar traditions. The application of Islamic law in the Ottoman Empire is a form of Islamic tolerance that allows other people to apply their respective laws, especially in the field of family law (private law), including behaviours that are contrary to Islamic law such as eating pork and consuming liquor, insofar as it is done in their environment (Taufiq Athar 2014, 13).

\section{The influence of Islamic law on the Church Qanun}

The religions of Masibiy have no religious law. There are only religious teachings, spirituality, morals that believe the separation between State and religion, as said by Jesus: "Give to the caesar what you must give to him and God what you must give to Him" (Matthew 22:21). The legislation is carried out by Christian religious leaders to create laws and regulations for the Christians.

The occupation of the Roman and Persian territories by Muslims had a lot of influence in various aspects, especially legal aspects. Islamic figh, through the various madhhabs, developed rapidly to be able to make the Church Qanun affected by it. This is because the interpretation of church laws is still limited, and is intended to fill the shortcomings in the existing sects (Syahatah 2016, 31). Many church experts refer to Islamic law and not the Roman-Byzantine law. Islamic sharia, in addition to the Roman Qanun, is one of the sources for the Eastern Church. Some examples can be seen in the book Yusa' Bakht about the laws in Christianity that have been written since 790 AD, or in Fiqh al-Masehi al-Kaldani written by Abu Farj Thayib in $1043 \mathrm{AD}$. The influence of Islamic fiqh can also be seen in the Coptic church law books written in the 11th century (Syahatah 2016, 32), or in the book Majmu' Shafawi by Ibnu Asal which cite many Islamic laws, especially fiqh from Maliki and Shafi'i 
schools. The book by Ibnu Asal is the primary reference in family law for the Orthodox Coptic Church (Syahatah 2016, 33).

\section{The Ottoman Tanzimat and Non-Muslim Minority Rights}

Islam guarantees the freedom of aqi dah and religious rituals for non-Muslims as well as their lives, possessions, and honour. Their economic activities are also protected by the Islamic judicial system (Qaradawi 1992). The Ottoman Empire was separated from the Islamic civilization promoted by the Abbasid dynasty in Baghdad and the Umayyads in Spain, which were more focused on science and not yet disturbed by the prolonged Crusades. The Ottoman Empire was an empire of champions (the Empire of Ghazis) with strong military basis (Shaw J Shaw 1976, 16). However, this country has not thought about developing an alternative economy by searching for information from the West and Russia. While Western Europe and Russia have ambassadors in Istanbul and throughout the territory of the Ottoman Empire, the Empire never had the desire to open its embassy in Europe and Russia because it sees the matter of economic development unimportant. Life in Western Europe and Russia is considered far from Islamic law. The crisis of leadership, the role of women in the palace, corruption, and so on made the Ottoman Empire face complex problems. The Ottoman Empire seemed to have taken a wrong medicine, that is, by marginalizing the Islamic law and adopting the Western European laws. The change occurred in $1774 \mathrm{AD}$, until the Ottoman Empire collapsed. An update attempt (reform) called Tanzimat Khairiyyah which was expected to bring goodness to the country has failed. The reform was carried out in the legal, political, social, cultural, economic, and educational fields, and has not yet reached the technology sector.

Minority groups have also played a role in this legal change because they hold important positions in the government body 
(Braude dan Lewis 1982. 114). The rights of capitulation, which provides legal immunity, tax freedom, and freedom of expression, have made them play a large role in the country's economy. They have become foreign agents who are also a political and economic burden for the Ottoman Empire. The groups are like a state within a state, i.e. the minority citizens who are under the legal protection of greedy foreign countries. The statesmen at that time saw the legal unity must be done. There must be no minority and majority law based on religion. There are only nationalism and legal unity that can restore the Ottoman Empire's sovereignty over all individuals in its territory (Farid Bek Al-Muhami 2009, 231). The Sultan's edict was issued in 1839 No. 189 (firman kulkhānah/gulhāne), which indirectly recognizes the decline of the Ottoman Empire because it has moved away from the teachings of Islamic law. Kanunname, which is not in line with Islamic sharia, has brought the country to the brink of collapse (Haqi 1988, 225). The religious gap is abolished in the name of legal equality adopted from the West. Sharia courts are limited in their scope, i.e. only in marital and divorce matters; religious, national, and ethnic benchmarks are excluded from law. The old economic and military system were abolished and leading the country to turbulence.

Khat Syarif Gulhāne is an agreement on rights, finance, administration, and military that has been announced to realize equality between the people in the Ottoman territory without discrimination, which is also contrary to Islamic law. Everyone is equal in court in accordance with the existing law, and she or he will not be punished without appeal and investigation. The iltizam system to draw taxes is cancelled, and the military service is limited to only five years (Hasri 1999, 88). Khat Syarif Gulhāne is a preliminary circular which is a promise to regulate the State in accordance with the Western European system, but 
it is not a constitution that can bind the sultan's policy (Mantran 2003, 331).

In short, tanzimat has brought the Ottoman Empire out of Islamic law. Individual Muslim relations turn into relationships between citizens based on nationalism. Non-Muslims lost their judiciary, and Muslims as the majority were more disadvantaged because they no longer applied Islamic law which was rooted in the aqidah and faith. Tanzimat also aims to limit and eliminate the absolute power possessed by the Sultan through the parliamentary, judicial system, and the constitution. It has added unity and integrity to non-Muslims who work together to make reforms in all fields. Meanwhile, Muslims do not get anything except depending on the ailing country. The tanzimat is fully implemented in Syria, Lebanon and Iraq, whereas in Hijaz and Yemen, it applies only to rules that are not principled.

\section{Millet Court and Social History of the Application of Non-Muslim Sharia}

Judicial Crisis in the Ottoman Empire

Judicial Crisis in the Ottoman Empire occurred when the political system began to turn away from Islamic law in the early $18^{\text {th }}$ century, along with the crisis of the State administration. The Ottoman Empire had given an excellent tolerance to non-Muslims not to submit to Islamic courts (Ahmad 2000, 155). The State also allows many other courts, such as consul trials throughout the region as a result of Foreign Capitulation. Solution of this problem has been found since the time of Khulafa ar-Rāshidīn. Muhammad bin Abu Bakr, for example, was once asked about the issue of adultery between a Muslim and a Christian that had been brought before the court. He gave it to the court. What law was applied to these two adulterers? He then asked the Caliph Ali ibn Abi Talib. Imam Ali ordered to implement the Islamic law for the Muslim and the Nasāra law for 
the Christian (Fattal 1995). However, this freedom was gradually reduced in line with the development of Islamic government policy at that time.

\section{Background of the Millet Court}

Prophet Muhammad PBUH entered into an agreement with the Jews in Medina when he had just moved from Mecca. The Prophet gave them freedom in carrying out religious rituals and the law. The Prophet said: "For Jews is their religion, and for Muslims is their religion" (Muhammad Hamidullah 1987, 57 64). When Umar bin Abdul Aziz asked Hasan al-Basri about interference in dhimi marriages, Hasan al-Basri replied: "they paid jizyah. Therefore, they may live according to their religious law" (Fattal 1995). Freedom for the minority groups becomes more specific from time to time because of the changes in understanding the court supremacy in the country. This has caused the non-Muslim parties to be freed to handle their abwāl shakhșiyyah matters (Fattal 1995). They are free to choose a court that will manage their case, i.e. either the Christian courts with their sects or the Islamic sharia courts. However, many non-Muslims have preferred the Islamic sharia courts to settle their cases since the time of Rasūlullah PBUH.

The freedom granted by the Ottoman government is also believed to be based on Islamic law. In the Ottoman territories, non-Muslim groups concentrated on a place with a certain number of populations consisting of independent sects. These sects are named al-Millah or Millet which is carved out by Orthodox Christians. Their group was called Rūm Millet, Millet-i Rūm, or simply the Romans. This name is a select name for the Eastern Orthodox Christian community in the Ottoman Empire. Most non-Muslims since the Byzantine period lived in the Galata village governed by the Archdiocese. Therefore, Greek, Serbian, Bulgarian, Roman, and even Orthodox Arabic Christians can 
be incorporated in the Millet-i R $\bar{u} m$ (Braude and Lewis 1982). After the Jews migrated from the massacre in Spain to the Ottoman Empire in $1492 \mathrm{AD}$, they also received the same rights as the Eastern Orthodox Christians. However, they have not yet joined the Millet system.

Meanwhile, Millet Armenia experienced changes in accordance with the passage of time. They are led by a Patriarch based in Istanbul. The religious leaders are the Millet leaders who also represent groups in religious and judicial matters. They have authority in administration. Therefore, the Millet leader is responsible for the Ottoman Turkish government (Aviv 2016).

\section{Millet Court and Absolute Freedom of Non-Muslim Citizens}

Freedom of rights and justice for the Orthodox Christians has long been recognized by the Ottoman Empire in accordance with the spirit of Islamic law. Freedom to practice religion, justice, and government administration for minorities is not the result of international treaties imposed by Russia due to the defeat of the war through the Küçük Kaynarca Antlaşması agreement in 1774. The agreement which states religious freedom for Orthodox Christians is part of the government policy named Kanunname. Meanwhile, Catholics and Protestants were not recognized in the Millet system until 1830 (İhsanoğlu, Sa 'dāwī, and Ihsānūğlū 1999). The large number of Christian groups and sects that do not include the Millet system are incorporated into the Armenian Patriarch regarding rights and justice (Ihsan Oglu, Akmaluddin and Sa'dawi, Salih 2011).

During the Tanzimat al-Khairiyah era, the absolute rights and freedom of religion had spread worldwide. Non-Muslim citizens are granted the privilege of being part of an international agreement. Many of them even have dual citizenship, so they have the right to impunity in accordance with the foreign citizenship they have, in addition to Ottoman citizenship. Or- 
thodox Christians at the time of Sultan Abdul Hamid II had been under Russian control due to the defeat of the war, which was carried out by Western incitement, to the Turkish parliament members, who wanted to take the Middle East and Balkan regions controlled by Russia. At this point, the minority groups have become political agents of countries that have interests in the Ottoman Empire through the Berlin Treaty in 1878 AD.

After the time of Sultan Abdul Hamid II, precisely in 1917 $\mathrm{AD}$, international agreements on freedom of rights and justice to non-Muslim groups were cancelled. Then, the family law (Private Law) which combines all sect and non-Muslim judiciaries were formed. The district court has become a standard reference for all Ottoman Turkish citizens. On October 25, 1917 AD, after Sultan Abdul Hamid II, a law containing 157 articles relating to Muslims, Jews and Christians were issued. Although the non-Muslim court was abolished and has become one judicial entity, aḥwāl shakhșiyyah (Private Law) law still applies to every religious adherent.

\section{Foreign Capitulation}

The Ottoman Empire gave many privileges to Western countries and Russia within the Ottoman territory not to submit to the Ottoman jurisdiction. They have legal immunity and tax relief. Moreover, foreign consuls have also granted these rights to non-Muslims by selling a certificate of capitulation. The capitulation has triggered legal westernisation because the system has made the loss of judicial sovereignty of the Ottoman Empire (Mughal and Sadiki 2017). From there, a dualism of the judiciary (legal authority) occurred, and the social chaos ensued.

The capitulation agreement has long been agreed upon and has become a standard rule since the time of Sultan Suleiman al-Qanuni in 1953 AD (Farid Bek Al-Muhami 2009). Islamic sharia applies to people who have Islamic faith, while the 
non-Muslims may not want such a law to apply to them. The capitulation was also given to facilitate European countries to expand trading activities and enrich gold coins circulating in the Ottoman Empire. It is also believed to be able to stimulate the economy and reduce inflation. Allowing non-Muslims to apply their laws and habits is part of the application of Islamic law as implied in the Qur'an (Fattal 1995).

It is said that Foreign Capitulation can ease disputes between Muslims and non-Muslims and is expected to succeed in maintaining diverse social integrity. Legal capitulation can also reduce the tension between Islam and the West after the Crusades. The separation of criminal, civil, and commercial law from Islamic law and making them a wad' $i$ law has made this Foreign Capitulation a catalyst for secular law in the Islamic world (Zuhaili 1992). Foreign capitulation is a phenomenon of the degradation of the application of Islamic sharia in the Ottoman Empire. Thus, all changes to the existing legal system in Arab countries followed the Foreign Capitulation system in the Ottoman Empire. The application of foreign capitulation is influenced by many factors, such as politics, trade, economy, psychology, thoughts, and foreign situations faced by the Ottoman Turks (Ihsan Oglu, Akmaluddin and Sa'dawi, Salih 2011).

\section{Tanzimat Institutions to Manage the Goodness for Non-Mus- $\lim$ Groups}

To regulate ethnicity, especially from non-Muslims, special institutions are needed to deal with their problems, either related to their internal problems or related to the issues between Muslims and foreign citizens. These institutions are as follows:

\section{The Millet System Institution}

This institution regulates the problems of non-Muslims in the country. They are given the right to appoint their spiritual leaders. The non-Muslims have special organizations and sys- 
tems in the fields of education, justice, and taxes that are governed by their spiritual leaders. The Millet System Institute is an intermediary between non-Muslim groups and the Ottoman Turkish government. Every religious leader or sect went to the sultan to receive the firmans (king's decree) which were part of the Kanunname. Later, they convey the firmans to their people and followers and oversee the application of these rules. Likewise, the non-Muslims convey their demands and desires through their leaders in accordance with the agreement with the Sultan. Muhammad al-Fatih is the founder of this Millet System, which had never existed in an Islamic state before. The term Ablu Dhimah is the product of the Arab dynasty towards the non-Muslims who are multi-madhabs. The Millet System is carried out in accordance with the Kanunname and the Sultan's firmans based on a single madhab, i.e. the Hanafi Madhab as the official school of the Ottoman Turkish Empire.

The Professional Sect Institutions (non-Muslim communities)

This institution is part of the Millet System, but it has special attention in the fields of industry, crafting, and the military. Non-Muslims who want to determine profits and regulate the market economy have a representative in the government. They are also given the task of solving administrative problems. They have a social assistance fund for their sect, which is weak and in need of financial assistance.

\section{The Nämah Law Institution}

This institution regulates the legal, political, social and economic aspects of non-Muslim settlements in the Ottoman territory. These non-Muslims are called the Musta'minin, including foreign citizens who live in the Empire.

\section{The Harim Institution}

This institution organizes and serves marriages of the sultans with non-Muslim foreign women. The high tolerance of 
Ottoman times was reflected in the comments of a Western adventurer named Gibbson when he toured the Ottoman Empire. He said: "When Jews were massacred by the inquisition court in Spain en masse, the Ottoman Turkish administration system provided security and social justice for all religious adherents in its territory" (Kazıcı 2009, 111).

\section{Conclusion}

Islamic sharia in the Kanunname is far more tolerant than Western legal products because the former has given many freedoms and autonomous rights to non-Muslim groups in carrying out religious rituals, financial administration, and even the judicial system in civil and criminal cases. The non-Muslims are given the freedom to choose whether they will settle their case in a special court for non-Muslims or in an Islamic sharia court. In this sense, Kanunname is understood as a manifestation of the authority of the sultans in regulating the Islamic government in the Ottoman Empire. Although the non-Muslim citizens are given the freedom to choose their religions, to carry out their judiciary, and regulate financial administration, this policy still caused turmoil, especially during the time of Sultan Abdul Hamid II. Here, Tanzimat is not entirely run smoothly due to internal crisis and external interference. Foreign powers have tried to change the tolerant Ottoman court system by making it a Western law without careful consideration. Hence, non-Muslim groups are considered to have played a role in dividing the country by becoming agents of the West through foreign capitulation, which provides impunity. During the time of Sultan Abdul Hamdi II in 1876 AD, jizyah was slowly abolished, or at least it changed in term of name and application, that is, it was no longer applied to civilians who joined the military. All are built on the principles of territory and citizenship, not Islam-based principles. 
ISLAMIC SHARIA AND NON-MUSLIM CITIZENS ...

\section{Bibliography}

Abdullah, Izzudin. 1973. Qanun al-Duwali al-Khaṣ. First. Vol. 2. 1 Kairo: Dar al-Wafa.

Ágoston, Gábor, and Bruce Alan Masters, 2009. Encyclopedia of the Ottoman Empire. New York: Facts on File Library of World History.

Ahmad, F. 2000. "Ottoman Perceptions Of The Capitulations 1800-1914." Journal of Islamic Studies 11 (1): 1-20. https://doi.org/10.1093/jis/11.1.1.

Aviv, Efrat. 2016. "Millet System in the Ottoman Empire." Oxford Bibliographies. New York: Oxford University Press. https://doi.org/10.1093/obo/9780195390155-0231.

Belge, Murat. 1985. Tanzimat'tan Cumburiyet'e Türkiye Ansiklopedisi. Vol. 12. 6 vols. Istanbul: İletişim.

Braude, Benjamin, and Bernard Lewis, 1982. Christians and Jews in the Ottoman Empire: The Functioning of a Plural Society. New York: Holmes \& Meier Publishers.

Aykut, Ebru. 2017. "Judicial Reforms, Sharia Law, and the Death Penalty in the Late Ottoman Empire." Journal of the Ottoman and Turkish Studies Association 4 (1): 7. https:// doi.org/10.2979/jottturstuass.4.1.02.

Farid Bek Al-Muhami, Muhammad. 2009. Tārikh al-Dawla al-'Aliyya al-'Uthmaniyya. Beirut: Dar al-Nafa'is.

Fattal, Antoine. 1995. Le Statut Légal des Non-Musulmans en Pays d'Islam. 2. Ed. Recherches de la Faculté des lettres et de sciences humaines Série 3, Orient chrétien 10. Beyrouth: Dar el-Machreq.

Finkel, Caroline. 2007. Osman's Dream: The Story of the Ottoman Empire, 1300-1923. New York: Basic Books.

Haqi, Ihsan. 1988. Daulah Uthmaniyah wa 'Alaqatuha al-Kharijiyyah. Beirut: Dar an-Nafais. 
Ihsan Oglu, Akmaluddin, and Sa'dawi, Salih. 2011. Daulah Utsmaniyah: Tarikh wa Hadharah. Istanbul: Markaz alAbhats li Tarikh wa Funun wa Tsaqafah Islamiyah.

İhsanoğlu, Ekmeleddin, Șālih Sa'dāwī, and Akmāl-ad-Dīn Ihsānūgulū. 1999. ad-Daula wa-'l-muğtama' wa-l-iqtiṣād. ad-Daula al- 'uțmānīya, tārīhn wa-ḥaḍāra / išrāf wa-taqdīm Akmāl-ad-Dīn Ihsānūḡì̃. Naqalahū ilā 'l-'arabīya Ṣālih Sa dāwī ; Muğallad 1. Isțanbūl: Markaz al-Abhạạ li-tTārīh wa-'l-Funūn wa-'ț-Taqāfa.

Inalcik, Halil. 2013. Ottoman Empire the Classical Age 13001600. London: Phoenix Press.

Kazıcı, Ziya. 2009. Sultan II Abdulhamid ve dönemi Osmanl Devleti. İstanbul: Kayıhan.

Mantran, Robert. 2003. Histoire de l'Empire ottoman. Paris: Fayard.

Mughal, Abdul Ghaffar, and Larbi Sadiki. 2017. "Shari'ah Law and Capitulations Governing the Non-Muslim Foreign Merchants in the Ottoman Empire." Sociology of Islam 5 (2-3): 138-60. https://doi.org/10.1163/2213141800503006.

Muhammad Hamidullah. 1987. Majmu'ah al-Watsaiq al-Siyasa li al-'Ahdi an-Nabawi wa Khilāfah al-Rashidah. Bayrut: Dar al-Nafa'is.

Huda, Nurul and Ahmad Muti. 2002. Keuangan publik Islam: pendekatan Al-Kharaj (Imam Abu Yusuf). Bogor: Penerbit Ghalia Indonesia.

Qaradawi, Yusuf. 1992. Ghairu al-Muslimin fì al-Mujtama' al-Islāmiy. al-Qahirah: Maktabat Wahbah.

Quataert, Donald. 2005. The Ottoman Empire, 1700-1922.2nd ed. New Approaches to European History. Cambridge, UK ; New York: Cambridge University Press. 
Shadiq Janbulat, Orhan. 2012. Qawānīn al-Dawlah al'Uthmāniyyah wa Șillatuhā bi al-Madhhab al-Hanafiy.

Syahatah, Syafiq. 2016. Itijah Tasyri'iyah fi Qawanin Bilad al-Arabiyah. Vol. 2. 1 vols. Maktabah al-Wafa.

Taufiq Athar, Abdunasir. 2014. Abkām Usrah Inda al-Masehiyin al-Misriyin wa Mada Tatbiquha fi Mahakim. Vol. 2. 1 vols. Kairo: Darul Amal.

Zarqa, Mustafa. 2001. Siyahgha as-Syar'iyah fi Ta'asuffi Isti'mal al-Haq. Third. Vol. 2. 1 vols. Beirut: Maktabah Nailah.

Zuhaili, Muhammad. 1992. Tarīkh al-Qad̄a fì al-Islām. Beirut: Muasasah Risalah. 
This page intentionally left blank 